\title{
Woman as Charismatic Leader at Pesantren
}

\author{
Hanifah Siti Nur Rohmah \\ Interdisciplinary Islamic Studies, UIN Sunan Kalijaga \\ hanifahsiti95@gmail.com
}

\begin{abstract}
Pesantren is an Islamic educational institution that shows the existence of a subculture in Indonesia. Pesantren is one of the educational institutions that are still strong and proud of the concept of charismatic leadership. Charismaticism in pesantren is often understood as leadership capable of having many obedient and loyal followers and good religious abilities and more often involves male leadership. Nyai Hj. Umi Azizah is well-known as a female leader in the Pesantren An nur who has extraordinary abilities / magical powers. This becomes very interesting for researchers to research Nyai Umi's charismatic leadership, which is based on extraordinary strength in accordance with Max Weber's charismatic theory. This research was conducted to know the charismatic leadership of Nyai Hj. Umi Azizah at the Al-Khodijah Dormitory, Pesantren An-Nur. The research was conducted using qualitative research methods with data collection techniques of observation, interviews, and documentation. From this research, it is known that Nyai Umi is considered to have charisma by her followers. Apart from having many loyal followers and good religious abilities like other charismatic leaders, Nyai Umi is called a charismatic leader because she has guardians in the form of supernatural beings, brings blessings, and her five senses are able to listen to 5 students in listening to memorization of the Al-Qur'an.
\end{abstract}

Keywords: Woman Leadership, Charismatic, pesantren, Supernatural.

\section{Introduction}

The development of science leads people to a world that is versatile and versatile. Technological advances touch various lines of community life, both in social life, culture, and education, including pesantren (Ifendi, 2020). Advances in science and technology lead society to critical and logical thinking, which is commonly called positivism. The development of positivism affects society's private life and influences people in choosing a leadership system in organizations. Positivism thinking that focuses on facts and logic guides people to choose institutions that lead society to the progress required by modernization (Ifendi, 2020). This institution usually will choose leaders who have clear accountability. 
Besides the situation in society in general, where metaphysical statements are considered meaningless, pesantren is one of the institutions that is still surviving its magical thinking. Without avoiding the truth of science and logic, pesantren can still develop rapidly during positivism development. In this case, the pesantren applies the principle (Hafidz, 2018) of al muhafadhotu 'ala al-qadiimi shaalih, wa al-akhdzu bi al-jadid al-ashlah (maintaining good old traditions and adopting new, better traditions).

Pesantren is one of the original Indonesian social institutions that function as a source of values, morality, controllers, and filters to develop morality and the community's spiritual life (Sahartini, 2004). The metaphysical flow in pesantren influences the leadership system used by the pesantren. Until now, pesantren are still proud to use a charismatic leadership system that seems so authoritarian.

Pesantren is not only famous for its charismatic leadership system but also its patriarchal system. Various mass media portray women as second only to men (Rahman, 2018). On the other hand, the interpretation of religion, both Islam and other religions that are biased toward gender, also influences people's thinking about men and women (Sukri \& Sofwan, 2001). Likewise, in pesantren, discussions about the leader of the pesantren or the owner of charisma, until now, they still side with men or are often referred to as Gus or Kiai in the pesantren.

In the modern era, many women have a high presence in leadership. In Indonesia, President Joko Widodo's administration is listed as the government with the most cabinet members (Hakim, 2018). In addition, there are also many female figures who are very influential in the development of Islam and pesantren such as Nyai Uswatun Hasanah Dhofir at Pesantren N.Q Sukorejo (Imroatul arifah, 2015), Nyai. Hj. Masriyah Amva at Pesantren Kebon Jambu Al-Islamy Cirebon (Munawaroh et al., 2019), Nyai Nur Latifah at Ma'had Aly Nurul Jadid Purbolinggo (Amalia \& Arifin, 2018), and Nyai Hj. Umi Habibah at Pesantren Darul Falah Sidoharjo (Azizah, 2014).

Several scholars have written about the role, position, and charisma of women, in this case, in the pesantren. Syarifatu Marwiyah (Marwiyah, 2016) states that a Nyai has legitimacy because she is a Kyai's wife. Women in pesantren are considered unable to hold positions independently. Viki Amalia and Zainal Arifin (Amalia \& 
Arifin, 2018) at they research about leadership type of Nyai Nur Latifah. They research found that: (1) the leadership type of Nyai Nur Latifah in preserving Kitab Kuning studies can be categorized as democratic and charismatic; (2) two factors are supporting her leadership: internal factors are religious competence and technological application ability, and external factors is support from the family council, special assembly for Kitab Kuning, and the guidance in Kitab Kuning reading (BMK), whereas, the challenging factors are related to the internal situation such as multiple roles as the leader of Fatayat NU and recitation, as well as external factors such as the decreased preference of students to learn Kitab Kuning and the negative impact of technology.

On the other hand, Fitri (Imroatul arifah, 2015), in her research, states that a Nyai (Nyai Uswarun Hasanah Dhofir) has charisma seen from the attitude and ability of her knowledge. Nyai is considered to have charisma because she can align herself with Kyai in East Java's batsul masail activities. On the other hand, in her research, Munawaroh (Munawaroh et al., 2019) argues that the leadership style he uses can be said to be a charismatic leadership style (in this study is Nyai Hj Masriyah Amva) where a Nyai always invites goodness and worship.

Nyai's leadership in the pesantren, namely (Hidayah \& Arifi, 2017) (1) as a full caregiver authority over the pesantren he takes care of, has three types of roles like a Kiai. For example, Nyai Hj. Umi Azizah at Pesantren An nur, (2) as the Kiai's companion who is responsible as the leader of the pesantren, but does not have full authority like Kiai (her husband), and (3) as caregivers which are limited to female students only.

In this study, research was conducted to determine the charismatic leadership of a Nyai named Nyai Hj. Umi Azizah. She is one of the Pesantren Annur leaders located in Ngrukem Hamlet, Pendowoharho Village, Sewon District, Yogyakarta. Nyai Umi's leadership was not motivated by her husband's existence as a Kyai; even Nyai Umi's husband is a well-known transportation entrepreneur in Jepara and lacks a background in good religious education. Nyai Umi was directly given a student by her father (KH. Nawawi Abdul Aziz) to accompany her to Al-Qur'an. There have been more and more Nyai Umi students from time to time; until now, there 
have been 320 students in the Al-Khodijah Dormitory, Pesantren Annur, which he leads independently.

Unlike the concept of charisma described in previous research, Nyai charismatic leadership's leadership is measured from both religious and social science and has many loyal followers. Charisma in this study refers to the charisma described by Marx Weber, namely the extraordinary power possessed by a person, which in this study is the extraordinary power possessed by Nyai Umi Azizah.

The research method used in this research is the descriptive qualitative research method. Descriptive qualitative research aims to provide an overview of a certain phenomenon in society (Sukandarrumidi, 2012). In this study, the researcher directly described the settings and findings in the Pesantren as a whole, especially those related to Nyaii Umi. Data collection is carried out through observation techniques or observations and notes made by a researcher on an object under study. Apart from observations, interviews and documentation were carried out so that the data obtained was accurate.

Data analysis was carried out using the approach of the charismatic leader Max Weber. Weber (Siagian, 2010) explains that charismatic leadership is leadership led by someone who is admired by many followers, even though sometimes the follower cannot explain why that person is admired. It is as if a charismatic leader (Riberu, 1992) is given a special task to be gifted with special talents by God to lead a group of people to navigate his life history challenges. These special talents can be in the form of the ability to walk on water, disappear, fly, and talents that are beyond ordinary human logic. This talent can also be an extraordinary power possessed by certain sacred objects. Charismatic leaders get their authority to lead from their abilities or extraordinary characteristics. It could also be due to the followers' belief that the leader has special characteristics, although sometimes it is difficult to prove.

\section{Woman as Charismatic Leader at Pesantren}

Pesantren Annur is an Islamic education institution located in Bantul Regency, Yogyakarta. The Pesantren An-Nur is divided into several dormitories: the AlKhodijah Dormitory led by Nyai Hj. Umi Azizah. Nyai Umi is one of the Nyai at the Pesantren Annur who is considered an Al-Qur'an expert and charismatic or 
considered to have some extraordinary abilities. Nyai Hj. Umi Azizah finished memorizing the Al-Qur'an by the time she was 16-17 years old. Her love for the AlQur'an can be seen from her dedication to teaching the Al-Qur'an, loving people who want to learn the Al-Qur'an, and their consistency in reading the Al-Qur'an. All of Nyai Umi's sons and daughters were also educated and grew up in pesantren based on the Tahfidzul Quran. Almost all of their sons and daughters had memorized the Al-Qur'an. The head of the Al-Khodijah dormitory said that Nyai Umi was one of the few Nyai at the Pesantren Annur whose memorization of the Al-Quran was very strong. This is due to the uniqueness of Nyai Umi reading the Al-Qur'an every day and listening to the memorization of the students.

There is no system of appointments and dismissals and charismatic leadership (A. Conger, 1997). Nyai Umi's father only ordered a few of his students to accompany Nyai Umi to recite the Al-Qur'an. Until now, many students are participating in reciting the Al-Qur'an with Nyai Umi. Nyai Umi can become a single parent for her six biological children and become a substitute parent for hundreds of santri who live in the Al-Khodijah Dormitory. As a substitute parent, Nyai Umi accompanies the students from waking up to bedtime activities. Nyai Umi wakes up the students by knocking on the student's room door or pressing the bell at the mosque.

There is no system of appointments and dismissals and charismatic leadership (A. Conger, 1997). Nobody appointed Nyai Umi as the leader. Nyai Umi's father only ordered a few of his students to accompany Nyai Umi to recite the Al-Qur'an. Until now, many students are participating in reciting the Al-Qur'an with Nyai Umi. Charismatics today are no longer like subtone particles that cannot be seen (A. Conger, 1997). The human eye can see today's charismatic leaders through daily behavior types. Nyai Umi has a very good relationship with the people around her because Nyai Umi is an open and helpful person. This made the people around him feel very familiar with Nyai Umi. Nyai Hj. Umi Azizah is known by the students, local residents, and the guardians of the student as an extraordinary Nyai.

Today the study of charismatic leadership still contains heated debates about the quality of charismatic leaders. Two elements contribute to charismatic mysticism (A. Conger, 1997). The first involves the relationship between charism and human perception. If we compare several charismatic leaders, it is not 
uncommon for us to know that one charismatic leader is different from another charismatic leader.

This is due to the existence of different perceptions and interpretations based on subjective human experiences. The second component which contributes to the mystical charism is world history. In this study, the researcher will categorize the first 3 points (point 1, 2, and 3) of Nyai Umi's extraordinary strength as a special charismatic characteristic of Nyai Umi who is different from other leaders, and the last 2 points (point 4 and 5) as the same findings of researchers as previous studies:

\section{Have "Angel" guard}

A charismatic leader (Riberu, 1992) was given a special task and was given special gifts and talents by God to lead a group of people to navigate his life history challenges. The students believe that Nyai Hj. Umi Azizah has Khodam. People who have long been involved in the supernatural world are undoubtedly familiar with the term Khodam. The term Khodam comes from Arabic, which in Javanese is known as perewangan. Perewangan, referred to here, is a supernatural figure who helps humans. Nyai Hj. Umi Azizah is a figure who is very careful about her memorization. In the Prophet's hadith, it is stated that Allah made for those who memorize the Al-Qur'an and keep their memorization, angels will be their friends.

The Javanese tradition has the belief that khodam does not come from the jinn or the angels. Khodam, in the Javanese tradition, is a supernatural being that has explicitly supernatural power or energy in an object or human. Unlike the Javanese tradition, the flow of wisdom states that khodam comes from Jin or an angel willing to help humans. This is based on the Al-Qur'an evidence, which explains that God created his servants who were intelligent in three groups, namely angels, jinn, and humans.

Rufus M. Jones (Romdon, 1993) argues that between the paths and levels of one's mystical journey through the purgative path (Purification). Purgative (Romdon, 1993) means cleansing. The purgative stage (Romdon, 1993) is divided into two models: purgative, ethical in nature, and purgative, which is ascetic. Purgative, which is ethical, means that someone who wants a mystical level must do good deeds and leave bad deeds. At the same time, purgative, 
which is ascetic, is an act that is considered torturing oneself because of too high a simplicity, such as eating less, fasting, not eating meat or rice, and so on. In the metaphysical theory, it is stated that khodam can be brought in or studied through several attempts. Khodam can be imported through a series of tirakat, rituals, fasting, and special wazifa. Khodam has two special characters, namely obedient and very loyal. Not just anyone can bring the essence of khodam.

Nyai Hj. Umi is one of the Nyai who is believed to have khodam by the people around her. Mawaddaturrohmah (Roroh) is one of the senior santri who believes in this, Roroh said that the mother often asked the management to wake her up at 02.00-03.00 to carry out night prayers. Roroh often feels other people's presence when he enters the house, while at Nyai Umi's house, Nyai Umi lives alone. Roroh believed that what he felt was the presence of khodam guarding Nyai Umi. In addition, Roroh also believes that Nyai Umi's face that never changes is also the result of the strengths of Nyai Umi.

Another case with Siti Marfu'ah, the head of the Al-Khodijah Dormitory, who felt the presence of khodam. Nyai Hj. Umi Azizah through her feelings of security when she was with Nyai Umi. Siti Marfu'ah felt that all this time, everyone who had escorted Nyai Umi away was always safe and her journey was always smooth. Siti Marfu'ah believed that this was none other than because there was a khodam who was always helping and guarding Nyai Umi's journey.

Safety during the trip was felt by Siti Mar'fuah and Nyai Umi's daughters (call ning for girl daughters or gus for man daughters). Ning Rif'ah said that he once took Nyai Umi to visit a relative in the Bantul area, Yogyakarta. When Ning Rif'ah accidentally hit a woman, the accident felt very fast. However, it did not feel like Ning Rif'ah and Nyai Umi was still standing upright in their place, not collapsing at all, while the mother who was hit was only a minor blister. According to Ning Rif'ah, what is extraordinary is that she felt that the accident occurred because of her negligence in riding a motorcycle. What happened was that the woman who ran into Ning Rif'ah felt guilty and apologized to Nyai Umi. Ning Rif'ah said that it was not the first time he experienced this; she had experienced it several times, including being saved from police raids. 
Another case with what was experienced by Najmi Fitriani, She is an alumnus of the Al-Khodijah dormitory. She told her story during an earthquake in Yogyakarta in 2016. The earthquake occurred during the recitation of the AlQur'an after dawn, at around 5:46 am. At that time, Nyai Umi was listening to 2 students at the mosque. The mosque is the oldest part of the Al-Khodijah dormitory. In the mosque, there is a large fan installed in the middle of the mosque. At that time, Najwi saw Nyai Umi directly embracing the two students to get out of the mosque, and unexpectedly the fan fell right after Nyai Umi passed. The Al-Khodijah dormitory building at that time only suffered minor damage. However, after the students and Nyai Umi left the dormitory, unexpectedly, the building outside the dormitory was seriously damaged.

The above students' experiences may not be easily believed by human logic, but it is still easily believed and believed by the followers of Nyai Umi. Although the story about Nyai Umi having a guardian angel cannot be proven scientifically, Nyai Umi still has high authority as a leader. According to Ritzer and Goodman, Charismatic leaders get their authority to lead from their abilities or extraordinary characteristics. It could also be due to the followers' belief that the leader has special characteristics, although sometimes it is difficult to prove (Ritzer George \& Goodman, 2010).

\section{The ability to listen to 3-5 students at once}

Nyai Umi not only has extraordinary strength in the form of a protective angel, but she also can listen to 3-5 students at once. Nyai Hj. Umi Azizah is a Nyai who is known to glorify the Al-Qur'an. She always kept her Al-Quran memorization. Bani Idris revealed that Nyai Umi never explained exactly how many Al-Qur'an chapters she read every day. However, Nyai Umi had advised Bani Idriz that for someone who has finished memorizing the Al-Qur'an, he is obliged to read the Al-Qur'an at least five juz a day. From this message, Bani Idris concluded that it is likely that Nyai Umi read the Al-Qur'an more than five juz a day. Siti Marfuah stated that Nyai Umi was wrong, one of the few Nyai at the Pesantren Annur who memorizes the Al-Qur'an very well. This is because Nyai Umi read the Al-Qur'an every day and listened to the memorization of the students. The number of students always increases every year. 
According to Bani Idris, Nyai Hj. Umi Azizah is a Nyai who can synchronize her five senses in more than three focuses, beyond ordinary humans' capabilities. Nyai Hj. Umi Azizah can listen to 5 wives at once. This is considered extraordinary because Nyai Umi operates both ears, mouth, eyes, and both hands simultaneously at different focuses. Bani Idris related that one time he deposited the memorization of Al-Quran to Nyai Umi along with four mothers who recited the Al-Qur'an to Nyai Umi. At that time, he forgot the passages he had deposited, simultaneously two mothers who recited the Al-Qur'an with him were also wrong, and at that time, Nyai Umi confirmed the reading of Bani Idriz and her hands tapped the table as a sign that the two mothers had mispronounced a verse.

It is different from the experience of Dewi Anggraeni, one of the tahfidz students of Al-Khodijah Dormitory. Nyai Umi, who sometimes travels out of town and gets home in the middle of the night or before dawn. This did not prevent Nyai Umi from listening to the students' memorization of Al-Qur'an. At times like this, Nyai Umi usually felt tired and even fell asleep when she listened to the students' Al-Quran memorization. Nyai Umi's sleep when the students were deposited was not a barrier for her students to continue reading their Al-Qur'an memorization to Nyai Umi. The student did not wake Nyai Umi while sleeping, and the students did not stop her deposit when Nyai Umi was asleep. The student continued to deposit the same as when Nyai Umi was awake, and when they finished their reading memories Al-Qur'an, they waited for Nyai Umi to wake up to Salim or shake hands and then go to the room. According to Dewi Aanggraeni, Nyai Umi can listen while sleeping. Based on her experience, Dewi had been corrected several times by memorizing her deposits when Nyai Umi fell asleep. Dewi was sure that Nyai Umi was really in a state of sleep because, at that time, Dewi could hear her snoring. Charismatics today are no longer like subtone particles that cannot be seen (A. Conger, 1997). The human eye can see today's charismatic leaders through daily behavior types.

According to Max Weber, it is as if a charismatic leader is given a particular task to be gifted with unique talents by God to lead a group of people to navigate the challenges of his life history (Riberu, 1992). The ability to listen to Nyai Umi is considered the extraordinary ability she has as a charismatic leader. The joy of 
Nyai Umi in reading the Al-Qur'an seems to have made all parts of her body memorized every verse of the Al-Qur'an. Nyai Hj. Umi Azizah can listen to five students at once.

\section{Rehabilitation of students}

The administrators of Al-Khodijah Dormitory think that Nyai Umi is too good a Nyai figure. Nyai Umi rarely refuses if there are students who want to study with him. So far, Nyai Umi still accepts students who have problems or are even expelled from other dormitories without considering the problem. Various kinds of students who are considered problematic have entered the Al-Khodijah dormitory, ranging from students who often steal, have relationships with the opposite sex, often run away from the hut, and so on. For Nyai Umi, the background to the problem is not important; the most important thing is that the students still want to study with her.

Charismatic leaders (Riberu, 1992) have high inspirations, courage, and confidence because charismatic leaders usually appear in crises that demand drastic changes. Initially, Nyai Umi students and daughters felt strange about Nyai Umi's decision to accept these problematic students because this could be a threat to the stability of Al-Khodijah Dormitory. However, over time with patience, diligence, and Nyai Umi's role model, based on observers of the management, the problematic students experienced changes for the better gradually. So far, there have been no students who have not changed after becoming Nyai Umi students; therefore, at this time, the management and the sons and daughters of Nyai Umi no longer object to Nyai Umi's decision to accept problematic students. In this case, Followers will not question the values, attitudes, behaviors and styles used by the charismatic leader (Siagian, 2010).

Nyai Umi's children believe that in the case of student admission problems, Nyai Umi has a high intuition. Students with problems often turn out to be good students in Nyai Umi's upbringing. As Weber said, charismatic leaders always have new ways of dealing with life's challenges (A. Conger, 1997).

\section{Have a loyal following}

The Al-Khodijah dormitory is located between the cemetery and the rice fields. In front of the Al-Khodijah Dormitory stands the burial complex of the 
Ngrukem hamlet; behind the dormitory, there is a stretch of rice fields, the right side is the backyard of the resident's house, which contains very lush bamboo trees, while the left side of the Al-Khodijah Dormitory is Junior Hight School and Senior High School building Annur. The location and shape of the Al-Khodijah Dormitory building are considered prone to crime from outside the dormitory and considered not meeting capacity, both in terms of the size of the building or the completeness and adequacy of the infrastructure.

The Al-Khodijah Dormitory was built with 16 rooms, nine bathrooms. 1118 students occupy one room of 3 square meters. The room will feel very crowded if all the occupants of the room sleep in the room. Some students choose to sleep at the mosque every night because the room can only be used for sleep by 6-8 people. For some students, the room only functions as a space for placing items. In contrast to other dormitories, 7-8 students are the same room size.

Buildings that are not suitable for capacity and inadequate infrastructure do not prevent Al-Khodijah Dormitory from becoming the dormitory of choice for new students and their parents. Many parents of students want their daughter to learn Al-Qur'an with Nyai Umi. According to Ning Rif'ah, students who registered at the Al-Khodijah Dormitory wanted to become simple Nyai Umi students, not because of the existing facilities. Not only guardians or students who want to recite the Al-Qur'an and be close to Nyai Umi, but also alumni and residents around the Pendowoharjo, Sewon, Bantul, Yogyakarta areas.

A student named Siti had experienced something extraordinary that he got from his dream. Siti is one of the students who feel uncomfortable living in the Al-Khodijah Dormitory. The mental and mental pressure made her often sick; in the end, she tried to leave the pesantren with Nyai Umi; at first, Nyai Umi didn't allow her; until then, she was allowed with a heavy heart. Siti moved to another pesantren, but unexpectedly for two months after leaving the Al-Khodijah dormitory, she often dreamed of meeting, getting advice, or reciting memories Al-Qur'an with Nyai Umi, from there. She decided to return to Al-Khodijah dormitory because she felt that Nyai Umi is a suitable teacher for her. Moreover, after a year after he returned to study with Nyai Umi, he memorized 20 juz AlQur'an and never got sick again. 
Charismatic leaders also have high authority, that sometimes they do not need much to influence someone to do what they want (A. Conger, 1997). AlKhodijah student alumni, both from the first batch, are still on good terms with Nyai Umi. They still feel they are obligated to come to Nyai Umi's house at least once a year. This is usually done when the anniversary of the death of the Pesantren Annur's founder, namely KH. Nawawi Abdul Azis and his wife, Nyai Hj. Walidah, SILATNAS (National Alumni Gathering), or during the Idul Fitri holidays. In addition, some alumni who are still domiciled in Yogyakarta, almost every year, still celebrate Nyai Umi's birthday.

Many alumni are from the Al-Khodijah dormitory or the central cottage, who have been visiting Nyai Umi. According to Siti Marfu'ah, their purpose of coming to visit included paying tribute to Nyai Umi, knowing the news of Nyai Umi and Pesantren Annur, asking for good blessings for getting married, opening a business, working or studying in other lodgings. In addition, sometimes they also come because they want to ask for solutions to their problems.

Weber (Siagian, 2010) explains that charismatic leadership is leadership led by someone who is admired by many followers, even though sometimes the follower cannot explain why that person is admired. This is evidenced by the cases above, where students feel they have a close bond with Nyai Umi. So that even though the student has graduated, he will continue to visit Nyai Umi's house regularly and even return to live in the pesantren again.

\section{Believed to be the spreader of blessings}

Taylor argues that religion is "The belief in the spiritual being," which means belief in a spiritual existence. Islam is a religion based on revelation. Unlike Christianity, which believes in God in human form, namely Jesus, Islam believes in God who is scientifically intangible and other considered illogical things such as blessings. In Arabic, barakah (Tuasikal, 2013) means the persistence of something. Muhammad bin Salih al-Uthaimin (Sodikin, 2017) defines blessings as a lot of goodness or the goodness of Allah SWT to something. A blessing can be in the form of health, smooth business, all smooth affairs, good work, a feeling of satisfaction and calm, a long life, a life of sufficiency, and so on. 
Blessings are not a gift from God that suddenly comes. Blessings can come through certain ways, such as many charities, increasing worship, or even blessings can also be obtained through pious people. In Islam, several ways are allowed and not allowed in seeking blessings. A Muslim is prohibited from seeking blessings using tabarruk with the graves of the Prophet, friends, or pious people and animals or other inanimate objects. Tabarruk, in this context, is praying to the expert of the grave, such as asking for prayers and blessings from the Prophet and taking blessings from his grave by kissing or rubbing the grave. In Islam, a Muslim is allowed to seek blessings through pious people because he does not equal that person's position with Allah. A pious person here is someone who is istiqomah in worship. His joy brings blessings to his life and the people around him.

Nyai Hj. Umi Azizah is a Nyai who consistent in worship. He is always consistent in carrying out sunna prayers and reading the Al-Qur'an. Every night he always told several senior students to be awakened to carry out the evening prayer in the congregation. Nyai Umi's strength does not only lie in her worship, but her expertise in educating students is also very well known by the wider community.

The greatness of Nyai Umi in worship and her simplicity in everyday life makes people around her believe that Nyai Umi is one of the pious people. The people around him believed that they would get blessings if they were near Nyai Umi. This is as told by Siti Marfu'ah.

Max Weber argues that a group led by a charismatic leader will feel attached to the leader with an inner bond and will embrace it with dedication (Rozak, 2004). Siti Marfuah is one of the students who most often accompanies Nyai Umi on the orders of Nyai Umi. Many experiences of Siti Marfu'ah with Nyai Umi.

Charismatic leaders (Mar'at, 1983) will use more loyal followers and often use bodyguards they trust. Siti Marfuah is one of Nyai Umi's students' beliefs, so she often accompanies Nyai Umi to go somewhere or an event. Siti Marfu'ah said that he had been asked to deliver Nyai Hj. Umi Azizah visited the house of one of the AlKhodijah dormitory alumni in the Slarong Bantul area. At that time, Nyai Hj. Umi Azizah did not know the alumni's exact house, so she had to ask people around the 
place. Suddenly a husband and wife arrived, who then greeted and shook hands with Nyai Umi with great respect. Nyai Umi is someone who is admired by many followers, and it is one of the dreams of a charismatic leader (Siagian, 2010).

The husband and wife then escorted Nyai Umi to the intended house; after that, Nyai Umi was ordered to stop by the husband and wife's house. Arriving there, unexpectedly all food and all drinks were served in front. The husband and wife hope that all the food and drinks served at Nyai Umi are abundant with their family's blessings. Through eating and drinking used by Nyai Umi, students also think that the hands that have been used to massage Nyai Umi's feet contain blessings, so the students often rub their hands over their faces or the whole body before doing other activities.

The respect of the student does not only apply to Nyai Umi but also Nyai's belongings. Students should not use all items worn by Nyai Umi. Like what happened to the pillow used by Nyai Umi as a backrest when listening to the students. The pillows are always in the prayer room, but the students never use the pillows. The students who rest at the mosque bring their pillows, as well as prayer mats, footwear, and so on. Currently, several items are used for students outside of their study hours with nyai, such as tables, which Nyai Umi uses to listen to the Al-Qur'an memorization by students. The public's belief that Nyai Umi can provide salvation to those around him and the admiration of Nyai Umi's followers for him, even Nyai Umi's belongings, is evidence of Nyai Umi's charismatic nature. Weber (Siagian, 2010) explains that charismatic leadership is leadership led by someone who is admired by many followers, even though sometimes the follower cannot explain why that person is admired.

The love of Nyai Hj. Umi Azizah, towards Al-Qur'an, has proven to make him have a high position before the students and society. With his diligence in teaching the Al-Qur'an, Nyai Umi became a figure that was followed by many people.

\section{Conclusion}

Leadership Nyai Hj. Umi Azizah is categorized in the charismatic leadership system because Nyai Umi is considered to have extraordinary power through extraordinary things that can be felt and seen, trusted, and believed by those closest 
to her. These extraordinary things include Nyai Umi's ability to listen to 3-5 students at once, assuming that Nyai Umi has a protector to be saved from various calamities and difficulties Nyai Umi is considered one the pious people who are one way of blessing. Different from leadership in the bureaucracy in general, Nyai Umi does not sort out the people who will become her students. Nyai Umi also does not receive the slightest material benefit from her leadership; she only gets respect, devotion to students, and donations as a thank you from the foundation and guardians Students.

\section{Suggestion}

Based on the research conclusions, research on the charismatic nature of a Nyai carried out by researchers still needs further research. Future research is expected to be able to explain the things that become the background for the emergence of charism from a leader; with the results of this research, the researcher can examine more deeply whether charismatic leaders who are based on extraordinary strengths can be learned or can only be obtained by people. Future research can also examine the scope or power of a charismatic leader.

\section{References}

Amalia, V., \& Arifin, Z. (2018). Kepemimpinan Nyai dalam Memelihara Kajian Kitab Kuning di Ma'had Aly Nurul Jadid Probolinggo. Jurnal Management Pendidikan Islam, 3, 215-230.

Azizah, L. (2014). Pengaruh Kharisma Ibu Nyai Hj. Umi Habibah terhadap Motivasi Menghafal Al-Qur'an Santri Putri Pondok Pesantren Darul Falah Sidoarjo. UIN Sunan Ampel.

Conger, J. A. (1997). Pemimpin Kharismatik. Binarupa Aksara.

Hafidz, B. Z. (2018). Pesantren dan Kemandirian Perekonomian: Studi tentang Kewirausahaan di Pondok Pesantren ArRisalah Cijantung IV Ciamis. Manageria: Jurnal Manajemen Pendidikan Islam, 3.

Hakim, R. N. (2018, March 14). Punya Menteri Perempuan Terbanyak di Kabinet, Jokowi Dapat Penghargaan dari DPR. Kompas.Com. https://nasional.kompas.com/read/2018/03/14/20243141/punyamenteri-perempuan-terbanyak-di-kabinet-jokowi-dapat-penghargaan-dari

Hidayah, S. N., \& Arifi, A. (2017). Women in Islamic Education. Jurnal Ulumuna, 21 (1), 138-142. 
Ifendi, M. (2020). Pesantren Dan Kepemimpinan Kiai: Studi Kasus Di Pondok Pesantren Mambaus Sholihin Gresik (1980-2020). Mudir (Jurnal Management Pendidikan), 2, 12-30.

Arifah, F. I. (2015). "Dinamika Kepemimpinan Nyai Uswatun Hasanah Dhofir dalam Pengelolaan Pondok Pesantren N.Q Sukorejo Situbondo". Universitas Jember.

Mar'at. (1983). Pemimpin dan Kepemimpinan. Ghalia Indonesia.

Marwiyah, S. (2016). Rekonfirmasi Identitas Nyai Di Pesantren. Jurnal Fenomena, 15, No 1.

Munawaroh, A., Fitri, V., \& Wajdi, F. W. (2019). Gaya Kepemimpinan Nyai Hajah Masriyah Amva Di Pondok Pesantren Kebon Jambu Alislamy Babakan Ciwaringin Kabupaten Cirebon. Jurnal Eduprof, 1, 78-93.

Rahman, F. (2018). Otoritas Keagamaan Nyai Pandalungan. Ancoms, 2, 959-970.

Riberu, J. (1992). Dasar-DasarKepemimpinan. Pedoman Ilmu Jaya.

Ritzer, G. D. \& Goodman, J. (2010). Teori Sosiologi Modern. Kencana.

Romdon. (1993). Tashawuf dan Aliran Kebatinan. LESFI.

Rozak, A. (2004). Kharisma Menuai Kuasa. Pustaka Marwa.

Sahartini. (2004). Managemen Pesantren. Pustaka Pesantren.

Siagian, S. P. (2010). Teori dan Praktek Kepemimpinan. Rineka Cipta.

Sodikin. (2017). Keberkahan. Islam Pos.

Sukandarrumidi. (2012). Metode Penelitian. Gajah Mada Press.

Sukri, S. S., \& Sofwan, R. (2001). Perempuan dan seksualitas dalam tradisi Jawa. Kerja sama Pusat Studi Wanita (PSW), IAIN Walisongo dengan Gama Media.

Tuasikal, M. A. (2013). Ngalap Berkah yang Diperbolehkan dan Dilarang. Muslim.or.Id. 